\title{
Front Matter: Volume 9254
}

, "Front Matter: Volume 9254," Proc. SPIE 9254, Emerging Technologies in Security and Defence II; and Quantum-Physics-based Information Security III, 925401 (1 December 2014); doi: 10.1117/12.2081410

SPIE. Event: SPIE Security + Defence, 2014, Amsterdam, Netherlands 


\title{
Emerging Technologies in Security and Defence II; and Quantum-Physics-based Information Security III
}

\author{
Mark T. Gruneisen \\ Miloslav Dusek \\ John G. Rarity \\ Keith L. Lewis \\ Richard C. Hollins \\ Thomas J. Merlet \\ Alexander Toet \\ Editors
}

22-23 September 2014

Amsterdam, Netherlands

Sponsored by

SPIE

Cooperating Organisations

TNO

European Optical Society

Published by

SPIE 
The CID Number appears on each page of the manuscript. The complete citation is used on the first page, and an abbreviated version on subsequent pages. Numbers in the index correspond to the last two digits of the six-digit CID Number.

The papers included in this volume were part of the technical conference cited on the cover and title page. Papers were selected and subject to review by the editors and conference program committee. Some conference presentations may not be available for publication. The papers published in these proceedings reflect the work and thoughts of the authors and are published herein as submitted. The publisher is not responsible for the validity of the information or for any outcomes resulting from reliance thereon.

Please use the following format to cite material from this book:

Author(s), "Title of Paper," in Emerging Technologies in Security and Defence II; and QuantumPhysics-based Information Security III, edited by M. T. Gruneisen, M. Dusek, J. G. Rarity, K. L. Lewis, R. C. Hollins, T. J. Merlet, A. Toet, Proceedings of SPIE Vol. 9254 (SPIE, Bellingham, WA, 2014) Article CID Number.

ISSN: 0277-786X

ISBN: 9781628413175

Published by

SPIE

P.O. Box 10, Bellingham, Washington 98227-0010 USA

Telephone +1 3606763290 (Pacific Time) · Fax +1 3606471445

SPIE.org

Copyright (C) 2014, Society of Photo-Optical Instrumentation Engineers.

Copying of material in this book for internal or personal use, or for the internal or personal use of specific clients, beyond the fair use provisions granted by the U.S. Copyright Law is authorized by SPIE subject to payment of copying fees. The Transactional Reporting Service base fee for this volume is $\$ 18.00$ per article (or portion thereof), which should be paid directly to the Copyright Clearance Center (CCC), 222 Rosewood Drive, Danvers, MA 01923. Payment may also be made electronically through CCC Online at copyright.com. Other copying for republication, resale, advertising or promotion, or any form of systematic or multiple reproduction of any material in this book is prohibited except with permission in writing from the publisher. The CCC fee code is 0277-786X/14/\$18.00.

Printed in the United States of America.

Publication of record for individual papers is online in the SPIE Digital Library.

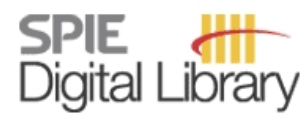

SPIEDigitalLibrary.org

Paper Numbering: Proceedings of SPIE follow an e-First publication model, with papers published first online and then in print and on CD-ROM. Papers are published as they are submitted and meet publication criteria. A unique, consistent, permanent citation identifier (CID) number is assigned to each article at the time of the first publication. Utilization of CIDs allows articles to be fully citable as soon as they are published online, and connects the same identifier to all online, print, and electronic versions of the publication. SPIE uses a six-digit CID article numbering system in which:

- The first four digits correspond to the SPIE volume number.

- The last two digits indicate publication order within the volume using a Base 36 numbering

system employing both numerals and letters. These two-number sets start with 00, 01, 02, 03, 04, 05, 06, 07, 08, 09, 0A, OB ... 0Z, followed by 10-1Z, 20-2Z, etc.

The CID Number appears on each page of the manuscript. The complete citation is used on the first page, and an abbreviated version on subsequent pages. Numbers in the index correspond to the last two digits of the six-digit CID Number. 


\title{
Contents
}

\author{
$\checkmark$ Authors \\ vii Conference Committee \\ xi Introduction to Part B: Emerging Technologies
}

\section{Part A Quantum-Physics-Based Information Security III} SATELLITE QUANTUM COMMUNICATION

925402 The NanoQEY mission: ground to space quantum key and entanglement distribution using a nanosatellite (Keynote Paper) [9254-1]

925404 Adaptive spatial filtering for daytime satellite quantum key distribution [9254-3]

PHOTON SOURCES, TRANSCEIVERS, AND REPEATERS FOR QUANTUM INFORMATION SYSTEMS

925405 Room-temperature single-photon sources based on nanocrystal fluorescence in photonic/plasmonic nanostructures (Invited Paper) [9254-4]

IMPLEMENTATION OF QUANTUM KEY DISTRIBUTION AND OTHER QUANTUM PROTOCOLS

9254 OB Quantum hyperdense coding [9254-9]

9254 OC Efficient quantum key distribution based on pulse-position modulation [9254-10]

9254 OD An in fiber experimental approach to photonic quantum digital signatures that does not require quantum memory [9254-11]

\section{QUANTUM COMPUTATION AND QUANTUM INFORMATION THEORY}

9254 Ol Programming non-trivial algorithms in the measurement-based quantum computation model [9254-16]

9254 0J A periodic probabilistic photonic cluster state generator [9254-17]

9254 OK Device-independent randomness extraction for arbitrarily weak min-entropy source [9254-18]

$9254 \mathrm{OL}$ Misinterpretation of statistical distance in security of quantum key distribution shown by simulation [9254-19] 
POSTER SESSION

9254 ON Special properties of single-photon optical fiber sensor for security needs [9254-21]

\section{Part B Emerging Technologies in Security and Defence II} SENSOR TECHNOLOGIES AND ISR

9254 OP High operating temperature SWIR HgCdTe APDs for remote sensing [9254-31]

9254 OQ Demonstration of an InAsBi photodiode operating in the MWIR [9254-32]

9254 OR The future dynamic world model (Keynote Paper) [9254-33]

9254 OS Photonically enabled Ka-band radar and infrared sensor subscale testbed [9254-34]

9254 OT Photonics and bioinspiration (Keynote Paper) [9254-36]

9254 OU Artificial human vision camera [9254-37]

\section{PHOTONIC SYSTEMS AND THEIR APPLICATION}

9254 OW Atmospheric energy harvesting: use of Doppler Wind Lidars on UAVs to extend mission endurance and enable quiet operations [9254-39]

9254 OX Active photonic sensor communication cable for field application of optical data and power transmission [9254-40]

$9254 \mathrm{OZ} \quad$ AIGalnN laser diode technology for defence, security and sensing applications [9254-42]

925410 Monolithic CMOS-MEMS integration for high-g accelerometers [9254-43]

\section{POSTER SESSION}

925411

Digital orthogonal receiver for wideband radar based on compressed sensing [9254-35] 


\section{Authors}

Numbers in the index correspond to the last two digits of the six-digit citation identifier (CID) article numbering system used in Proceedings of SPIE. The first four digits reflect the volume number. Base 36 numbering is employed for the last two digits and indicates the order of articles within the volume. Numbers start with 00, 01, 02, 03, 04, 05, 06, 07, 08, 09, OA, OB...0Z, followed by 10-1Z, 20-2Z, etc.

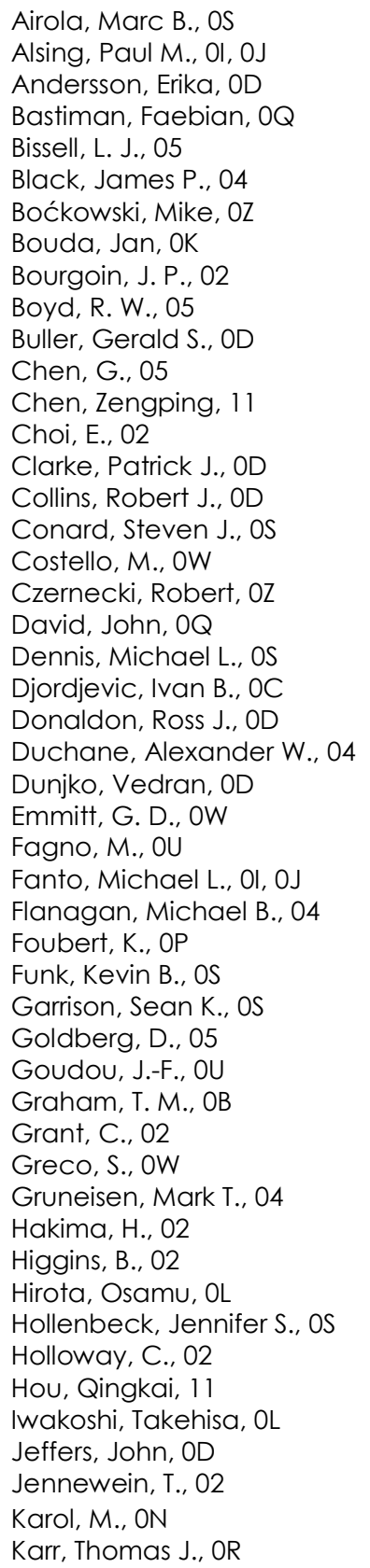

\author{
Kelly, Antony E., OZ \\ Kim, Richard S., OJ \\ Kucharski, Robert, $\mathrm{OZ}$ \\ Kwiat, P. G., OB \\ Largeron, C., OP \\ Lasfargues, G., OP \\ Leszczyński, Mike, $0 z$ \\ Lewis, Keith, 0T \\ Li, Holden, 10 \\ Liapis, Andreas C., 05 \\ Liu, Yang, 11 \\ Lohr, Michele B., OS \\ Lott, Gordon E., Ol, OJ \\ Lukishova, S. G., 05 \\ Maggio, S., OU \\ Markowski, Piotr, ON \\ Marona, Lucja, $\mathrm{OZ}$ \\ Menon, V. M., 05 \\ Mihaylova, D., 05 \\ Mosberger, M., OP \\ Najda, Stephen P., OZ \\ Napierala, M. S., ON \\ Narasimhan, Vinayak, 10 \\ Neifeld, Mark A., OC \\ Osman, Joseph M., OJ \\ Pavek, Richard E., OS \\ Pawłowski, Marcin, OK \\ Perlin, Piotr, $\mathrm{OZ}$ \\ Pivoluska, Matej, OK \\ Plesch, Martin, OK \\ Prasad, P., 05 \\ Preble, Stefan F., 0J \\ Pugh, C., 02 \\ Richards, Robert D., $\mathrm{OQ}$ \\ Rieske, Ralf, OX \\ Rothman, J., OP \\ Sandall, Ian C., OQ \\ Shi, Z., 05 \\ Sickmiller, Brett A., 04 \\ Smith, A. Matthew, Ol, OJ \\ Sodnik, Z., OP \\ Sova, Raymond M., OS \\ Stoltenberg, Kurt E., 04 \\ Su, Shaoying, 11 \\ Suski, Tadek, $\mathrm{OZ}$ \\ Suthau, Eike, OX \\ Szep, Attila, 0J \\ Szustakowski, M., ON \\ Tan, Chee Hing, $O Q$
}


Tan, Chuan Seng, 10

Targowski, Grzegorz, $\mathrm{OZ}$

Terry, David H., OS

Tison, Christopher C., Ol, OJ

Wallden, Petros, OD

Watson, Scott, $\mathrm{OZ}$

White, Ben, $O Q$

Widmer, J., OP

Winkler, J. M., 05

Wisniewski, Przemek, $0 Z$

Wood, S. A., OW

Zayer, I., OP

Zee, R., 02

Zerna, Thomas, OX

Zhang, Yequn, OC

Zyczkowski, M., ON

Proc. of SPIE Vol. $9254925401-6$

Downloaded From: https://www.spiedigitallibrary.org/conference-proceedings-of-spie on 26 Apr 2023 Terms of Use: https://www.spiedigitallibrary.org/terms-of-use 


\section{Conference Committee}

Symposium Chair

David H. Titterton, Defence Science and Technology Laboratory

(United Kingdom)

Symposium Co-chairs

Reinhard Ebert, Fraunhofer-Institut für Optronik, Systemtechnik und Bildauswertung (Germany)

Ric H. Schleijpen, TNO Defence, Security and Safety (Netherlands)

\section{Part A: Quantum-Physics-Based Information Security}

\section{Conference Chairs}

Mark T. Gruneisen, Air Force Research Laboratory (United States)

Miloslav Dusek, Palacký University Olomouc (Czech Republic)

John G. Rarity, University of Bristol (United Kingdom)

Conference Programme Committee

Jan Bouda, Masaryk University (Czech Republic)

Robert W. Boyd, University of Ottawa (Canada)

Gerald S. Buller, Heriot-Watt University (United Kingdom)

Ryan Camacho, Sandia National Laboratories (United States)

John D. Gonglewski, European Office of Aerospace Research and Development (United Kingdom)

Richard J. Hughes, Los Alamos National Laboratory (United States)

Gregory S. Kanter, NuCrypt LLC (United States)

Prem Kumar, Northwestern University (United States)

Norbert Lütkenhaus, University of Waterloo (Canada)

Vadim V. Makarov, Norwegian University of Science and Technology (Norway)

Ronald E. Meyers, U.S. Army Research Laboratory (United States) Jane E. Nordholt, Los Alamos National Laboratory (United States) Miles J. Padgett, University of Glasgow (United Kingdom) Momtchil Peev, Austrian Research Centres GmbH - ARC (Austria) Renato Renner, ETH Zürich (Switzerland)

Andrew J. Shields, Toshiba Research Europe Ltd. (United Kingdom) Rupert Ursin, Austrian Academy of Sciences (Austria) 
Session Chairs

1 Satellite Quantum Communication

Ryan Camacho, Sandia National Laboratories (United States)

2 Photon Sources, Transceivers, and Repeaters for Quantum

Information Systems

Miloslav Dusek, Palacký University Olomouc (Czech Republic)

3 Implementation of Quantum Key Distribution and other Quantum Protocols

Mark T. Gruneisen, Air Force Research Laboratory (United States)

4 Continuous Variables Approaches to Quantum Key Distribution

Rupert Ursin, Austrian Academy of Sciences (Austria)

5 Quantum Computation and Quantum Information Theory

Timothy Ralph, The University of Queensland (Australia)

\section{Part B: Emerging Technologies}

\section{Conference Chairs}

Keith L. Lewis, Sciovis Ltd. (United Kingdom)

Richard C. Hollins, Defence Science and Technology Laboratory (United Kingdom)

Thomas J. Merlet, Thales Optronique S.A.S. (France)

Alexander Toet, TNO Defence, Security and Safety (Netherlands)

Conference Programme Committee

Tibor Berceli, Budapest University of Technology and Economics

(Hungary)

Gerald S. Buller, Heriot-Watt University (United Kingdom)

John J. R. David, The University of Sheffield (United Kingdom)

Didier Decoster, Université des Sciences et Technologies de Lille

(France)

Daniel Dolfi, Thales Research \& Technology (France)

John D. Gonglewski, European Office of Aerospace Research and Development (United Kingdom)

Hugh D. Griffiths, University College London (United Kingdom)

Dominique Hamoir, ONERA (France)

Andrew R. Harvey, University of Glasgow (United Kingdom)

Steven R. Jost, BAE Systems (United States)

Robert A. Lamb, SELEX Galileo Ltd. (United Kingdom)

Javier Marti-Sendra, Universidad Politècnica de València (Spain)

Stephen P. McGeoch, Thales Optronics Ltd. (United Kingdom) 
Miguel A. Piqueras, DAS Photonics (Spain)

Julien Poette, Institut National Polytechnique de Grenoble (France)

Ian K. Proudler, Malvern Innovations (United Kingdom)

Robert Rehm, Fraunhofer-Institut für Angewandte Festkörperphysik

(Germany)

Kevin Ridley, Malvern Innovations (United Kingdom)

Béla Szentpáli, Research Institute for Technical Physics and Materials Science (Hungary)

Mauro G. Varasi, Finmeccanica (Italy)

Jean-Pierre Vilcot, Université des Sciences et Technologies de Lille (France)

\section{Session Chairs}

6 Sensor Technologies and ISR

Keith L. Lewis, Sciovis Ltd. (United Kingdom)

Richard C. Hollins, Defence Science and Technology Laboratory (United Kingdom)

7 Photonic Systems and their Application

Alexander Toet, TNO Defence, Security and Safety (Netherlands)

Keith L. Lewis, Sciovis Ltd. (United Kingdom) 
Proc. of SPIE Vol. $9254925401-10$

Downloaded From: https://www.spiedigitallibrary.org/conference-proceedings-of-spie on 26 Apr 2023 Terms of Use: https://www.spiedigitallibrary.org/terms-of-use 


\section{Introduction to Part B: Emerging Technologies}

This conference brought together emerging activities in photonic technologies, including discriminative imaging, computational imaging, micro- and nanotechnology sensors, photonic micro-devices, spectroscopic technologies and energy harvesting techniques, within the context of their associated defence exploitation as well as their potential civilian application. To help focus interest, the conference sessions were deliberately organised around a group of four keynote presentations, highlighting the growing impact of plasmonic technologies, the relevance of bio-inspiration for sensors, as well as accounts of selected programs being supported by DARPA's Strategic Technology Office and a review of active electro-optic (EO) imaging recently carried out by the National Research Council of the US Academies. Other papers covered research on EO detectors for the SWIR and MWIR bands, CMOS-MEMS integration, quaternary laser diodes for the blue spectral band and the exploitation of photonics in radar systems and for data/power transmission.

Keith L. Lewis

Richard C. Hollins

Thomas J. Merlet

Alexander Toet 
Proc. of SPIE Vol. $9254925401-12$

Downloaded From: https://www.spiedigitallibrary.org/conference-proceedings-of-spie on 26 Apr 2023 Terms of Use: https://www.spiedigitallibrary.org/terms-of-use 